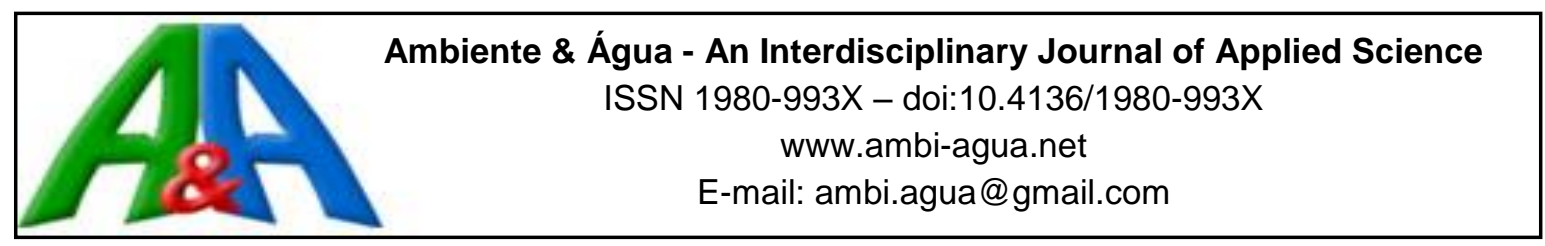

\title{
Combined water treatment with extract of natural Moringa oleifera Lam and synthetic coagulant
}

\author{
ARTICLES doi:10.4136/ambi-agua.2135 \\ Received: 16 May 2017; Accepted: 06 Mar. 2018
}

\author{
Karina Cardoso Valverde ${ }^{1}$; Edneia Aparecida de Souza Paccola ${ }^{2}$; \\ Armando Mateus Pomini ${ }^{3}$; Natália Ueda Yamaguchi ${ }^{2 *}$; Rosangela Bergamasco ${ }^{1}$ \\ ${ }^{1}$ Universidade Estadual de Maringá (UEM), Maringá, PR, Brasil \\ Departamento de Engenharia Química. E-mail: karinacvalverde@gmail.com, \\ ro.bergamasco@hotmail.com \\ ${ }^{2}$ Centro Universitário de Maringá (Unicesumar/ICETI), Maringá, PR, Brasil \\ Departamento de Tecnologias Limpas. E-mail: edneia.paccola@unicesumar.edu.br, \\ nataliaueda@hotmail.com \\ ${ }^{3}$ Universidade Estadual de Maringá (UEM), Maringá, PR, Brasil \\ Departamento de Química (DQI).E-mail: ampomini@uem.br \\ *Corresponding author
}

\begin{abstract}
This study evaluated the efficiency of coagulation/flocculation, sedimentation and filtration processes using the combination of natural coagulant from Moringa oleifera Lam (MO) and synthetic coagulant aluminum polychloride (PAC) for water treatment. Raw water was obtained from the Pirapó River Basin, Maringá, Paraná State, Brazil. Coagulation/flocculation and sedimentation assays were carried out in a Jar Test. A two-layer rapid filter filled with sand and anthracite was used in the filtration stage. Water quality and therefore the efficiency of the process were determined by means of the analysis of physical, chemical and bacteriological parameters, including the determination of floc size and zeta potential. The utilization of MO contributed to the reduction of the required demand of synthetic coagulant PAC. The association of coagulants, with $80 \% / 20 \%$ or $60 \% / 40 \%$ of $\mathrm{MO} / \mathrm{PAC}$, ensured an improvement of water quality parameters, such as apparent color, turbidity and $\mathrm{UV}_{254 \mathrm{~nm}}$, as well as the possibility of water production with adequate potability standard.
\end{abstract}

Keywords: aluminum polychloride, conventional water treatment, Moringa oleifera Lam.

\section{Tratamento de água combinado com extrato natural de Moringa oleifera Lam e coagulante sintético}

\section{RESUMO}

O presente estudo consistiu em avaliar a eficiência dos processos de coagulação/floculação, sedimentação e filtração, utilizando a associação do coagulante natural obtido de Moringa oleifera Lam (MO) e do coagulante sintético policloreto de alumínio (PAC) para tratamento de água. Foi utilizada água bruta proveniente da bacia do Rio Pirapó, Maringá, PR, Brasil. Os ensaios de coagulação/floculação e sedimentação foram realizados em Jar Test. $\mathrm{Na}$ etapa de filtração utilizou-se um filtro rápido de camada dupla de areia e antracito. A 
qualidade da água e a eficácia do processo foram avaliadas por meio da análise de parâmetros físicos, químicos e bacteriológicos, além da determinação do tamanho dos flocos e potencial zeta. A utilização da MO contribuiu para a redução da demanda requerida do coagulante sintético PAC. A associação dos coagulantes com 80\%/20\% ou 60\%/40\% de MO/PAC garantiram a melhoria dos parâmetros de qualidade, tais como cor aparente, turbidez e $U_{254 n m}$, assim como a possibilidade de produção de água com o padrão de potabilidade adequado.

Palavras-chave: Moringa oleifera Lam, policloreto de alumínio, tratamento convencional de água.

\section{INTRODUCTION}

Water quality has significantly deteriorated and drinking water access has become one of the major problems faced due to rising populations and industrialization, especially in developing countries (Tukki et al., 2016). The World Health Organization (WHO) estimates that 1.8 billion people in the World still do not have access to drinking water and more than 800,000 people are estimated to die of diarrhea as a result of low-quality drinking water, sanitation and poor hand hygiene every year (WHO UNICEF, 2015). Hence, new technologies for water treatment are essential for the reduction of pollutants, especially pathogens, producing safe water for human consumption according to technical parameters required by law.

Synthetic coagulants have been widely used in conventional water treatment processes, especially in the stages of coagulation/flocculation, filtration and sedimentation. Among them, aluminum polychloride (PAC), which is an inorganic polymer, stands out since it has a rapid aggregation speed, forms heavy flocs and requires lower dosages of coagulant, leading to a smaller volume of sludge. Moreover, it can be easily replaced by other synthetic coagulants, such as aluminum sulfate and ferric chloride (Srivastava et al., 2005). Additionally, it has been widely studied since it exhibits better efficiency than other coagulants for color and turbidity removal and has smaller temperature and $\mathrm{pH}$ dependence (Pisoi, 2011).

Despite the well known performance and cost-effectiveness of synthetic coagulants, mainly aluminum sulphate and PAC, one of the major problems of these conventional products is the residual aluminum content present in water after treatment, which has been linked to Alzheimer's disease (Bongiovani et al., 2015).

The use of natural coagulants has been studied as an interesting alternative for water treatment, primarily due to their abundant availability, low cost, non-toxicity, and multifunctional behavior (Bhuptawat et al., 2007; Tukki et al., 2016).

Among the natural coagulants, Moringa oleifera Lam (MO) stands out as one of the mostused (Ndabigengesere et al., 1995). It is native to northern India, belonging to the Moringaceae family, which is composed of one unique genre (Moringa) and 14 species (Anwar et al., 2007; Meneghel et al., 2013). It is adapted to habitats with low pluviometric indexes and hot climates and does not require any specific type of soil. However, it does not develop properly at low temperatures, which can be a major drawback for biomass production in several parts of the World (Poumaye et al., 2012).

It is assumed that MO seeds act as a coagulant in water clarification due to the presence of a soluble, high molecular weight cationic protein, which can reduce the turbidity of treated water (Ndabigengesere et al., 1995).

According to Valverde et al. (2018) MO does not alter significantly the $\mathrm{pH}$ (Awad et al. 2013) and alkalinity of water after treatment (Ndabigengesere and Narasiah, 1998). The sludge produced during the coagulation process is innocuous because all MO byproducts are organic, non-toxic and biodegradable (Ndabigengesere et al., 1995). Furthermore, MO seeds also have antimicrobial activity (Joshua and Vasu, 2013). 
Aiming to improve the efficiency in coagulation/flocculation processes with MO, several researchers have studied its association with synthetic coagulants, such as aluminum sulfate, ferric chloride, PAC and anionic polymers (Awad et al., 2013; Bongiovani et al., 2014; David et al., 2016; Freitas et al., 2016; Ghebremichael et al., 2009; Valverde et al., 2013; Valverde, et al., 2015). However, there is still a shortage of comprehensive studies comparing the efficiency of coagulant associations (Yin, 2010).

Thus, considering the coagulant properties of MO and PAC, the present work evaluated the efficiency of coagulation/flocculation, sedimentation and filtration processes using the association of these coagulants in raw water treatment processes.

\section{MATERIALS AND METHODS}

Raw water samples were collected from a public water-treatment system (WTS), Paraná Sanitation Company (Companhia de Saneamento do Paraná, SANEPAR), located in Maringá City, Paraná State, Brazil. The surface water is from the Pirapó river basin. Water characterization before and after treatment was carried out by means of quality parameters such as floc size, zeta potential (Delsa Nano ${ }^{\mathrm{TM}} \mathrm{C}$ Beckman Coulter), apparent color, $\mathrm{UV}_{254 \mathrm{~nm}}$ absorption (DR 5000 Hach Spectrophotometer), turbidity (2100P Hach Turbidimeter), temperature (L-151/08 Incoterm Thermometer), $\mathrm{pH}$ (Thermo Scientific Orion VSTAR92 Versastar Meter), DOC (TOC-L CPH Shimadzu Total Organic Carbon Analyzer), total trihalomethanes (TTHM) (Internal Standard Addition Method), alkalinity and volatile acids, total hardness, total dissolved solids (TDS) (APHA et al., 1995), total coliforms and Escherichia coli (TM EC 3M Petrifilm plate).

\subsection{Coagulant preparation}

Natural coagulant was prepared with $15 \mathrm{~g}$ of previously peeled MO seeds from Aracaju, Sergipe, Brazil. The seeds were ground in a household blender for 3 minutes and dried in an oven at $40^{\circ} \mathrm{C}$ until reaching constant weight.

Synthetic coagulant was prepared with a $1 \%(\mathrm{v} / \mathrm{v})$ concentration, $1 \mathrm{~mL}$ of PAC in a $100 \mathrm{~mL}$ volumetric flask and filled up to the mark with distilled water.

\subsection{Coagulation/flocculation and sedimentation process}

Coagulation/flocculation assays were carried out in a six-paddle stirrer Jar Test with a regulated paddle speed, using $700 \mathrm{~mL}$ of raw water.

The maximum dosages were adapted according to values cited in the literature as $50 \mathrm{mg} \mathrm{L}^{-1}$ for MO (Baptista et al., 2015) and $12.5 \mathrm{mg} \mathrm{L}^{-1}$ for PAC (Zouboulis and Tzoupanos, 2010). Coagulant dosages used in the assays are presented in Table 1.

Table 1. Coagulant dosages used in the association MO/PAC for water treatment.

\begin{tabular}{|c|c|c|c|c|c|c|c|}
\hline \multicolumn{2}{|c|}{ \% Coagulant (MO/PAC) } & \multirow{2}{*}{$\begin{array}{c}100 / 0 \% \\
50 \\
0.00\end{array}$} & \multicolumn{4}{|c|}{$90 / 10 \%$ 80/20\% 70/30\% 60/40\% } & $50 / 50 \%$ \\
\hline Dosage $\left(\mathrm{mg} \mathrm{L}^{-1}\right)$ & $\begin{array}{l}\text { MO } \\
\text { PAC }\end{array}$ & & $\begin{array}{l}45 \\
1.25\end{array}$ & $\begin{array}{l}40 \\
2.50\end{array}$ & $\begin{array}{c}35 \\
3.75\end{array}$ & $\begin{array}{c}30 \\
5.00\end{array}$ & $\begin{array}{l}25 \\
6.25\end{array}$ \\
\hline
\end{tabular}

Optimal operational conditions were experimentally determined in a previous study (Valverde et al., 2015) for the association of MO seeds and PAC coagulants as being: $100 \mathrm{rpm}$ for 1 minute in order to provide rapid mixing; $45 \mathrm{rpm}$ for 15 minutes in order to provide slow mixing and 15 minutes for sedimentation.

After the coagulation/flocculation and sedimentation process, samples of treated water were collected from each one of the flasks with the aid of a $20 \mathrm{~mL}$ graduated pipette.

\section{IPABH}

Rev. Ambient. Água vol. 13 n. 3, e2135 - Taubaté 2018 
To compare the results, variance analysis (ANOVA) and Tukey Test were carried out at a $95 \%$ confidence interval, with a significant $p$-value $<0.05$, in order to verify the significant differences. The SISVAR statistical program was used (version 5.3) (Ferreira, 2011).

\subsection{Filtration step}

A rapid downflow filtration process was used after the coagulation/flocculation and sedimentation assays, using treated water, as illustrated in Figure 1.

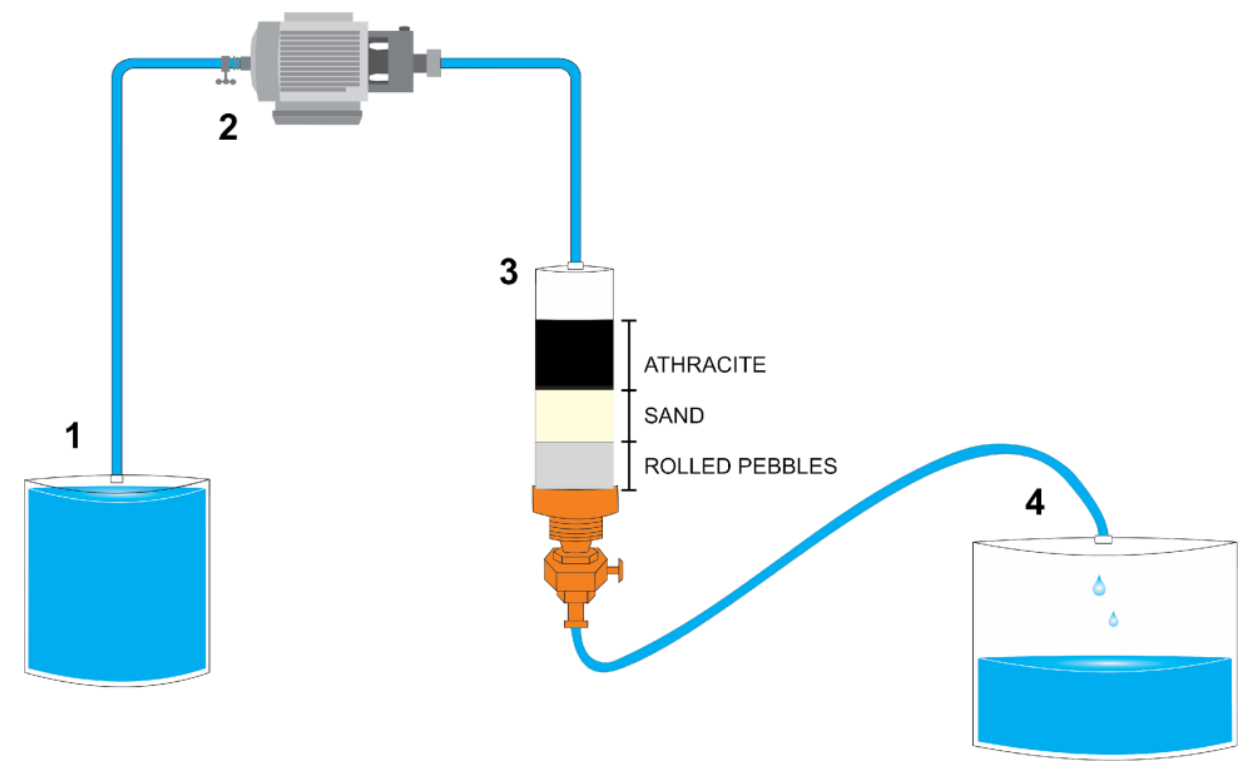

Figure 1. Scheme of rapid downflow filtration process.

The process consisted of a feed tank (1) and a continuous-flow filter feeding was carried out by means of a peristaltic pump (2). A filtration rate of $240 \mathrm{~m}^{3} \mathrm{~m}^{-2}$ day $^{-1}$ was adopted (equivalent to a flow rate of $535 \mathrm{~mL} \mathrm{~min}^{-1}$ ). An acrylic column (3) with an internal diameter of $6.4 \mathrm{~cm}$, a length of $35 \mathrm{~cm}$ with double-layer, and deep-bed filtration was used. The $20 \mathrm{~cm}$ highfiltration column was built with materials provided by SANEPAR, previously washed, with a $6 \mathrm{~cm}$-thick layer of sand with granulometry between $0.42 \mathrm{~mm}$ and $2.00 \mathrm{~mm}$, and a $9 \mathrm{~cm}$-thick layer of anthracite with granulometry between 0.71 and $2.40 \mathrm{~mm}$, supported on a screen and a $5 \mathrm{~cm}$ layer of rolled pebbles with sizes between $1 / 4$ " and $1 / 8$ ". Flow rate measurement was performed at the filter outlet (4) every $3 \mathrm{~min}$, and the starting point for treated water sample collection occurred in the final minute of filtration, that is, after a 15-min time span for a total period of filtration of $21 \mathrm{~min}$, in order to assure assay uniformity.

\section{RESULTS AND DISCUSSION}

Figure 2 presents the results for removal parameters of apparent color, turbidity and compounds with $\mathrm{UV}_{254 \mathrm{~nm}}$ absorption obtained with the combination of coagulants.

The utilization of greater proportions of MO as coagulant in the coagulation/flocculation and sedimentation processes led to lower removal efficiencies, with $70.1 \%, 75.1 \%, 56.7 \%$ for removal of apparent color, turbidity, and $\mathrm{UV}_{254 \mathrm{~nm}}$ absorption, respectively. However, its use as an adjuvant to PAC was interesting, since good results for all parameters were then observed. It also diminished the amount of process residues, which is in agreement with Valverde et al. (2013), Valverde et al. (2015), and Ghebremichael et al. (2009). Dalen et al. (2009) observed the same synergy when PAC and MO seed powder were blended and used in water treatment than using pure MO. 

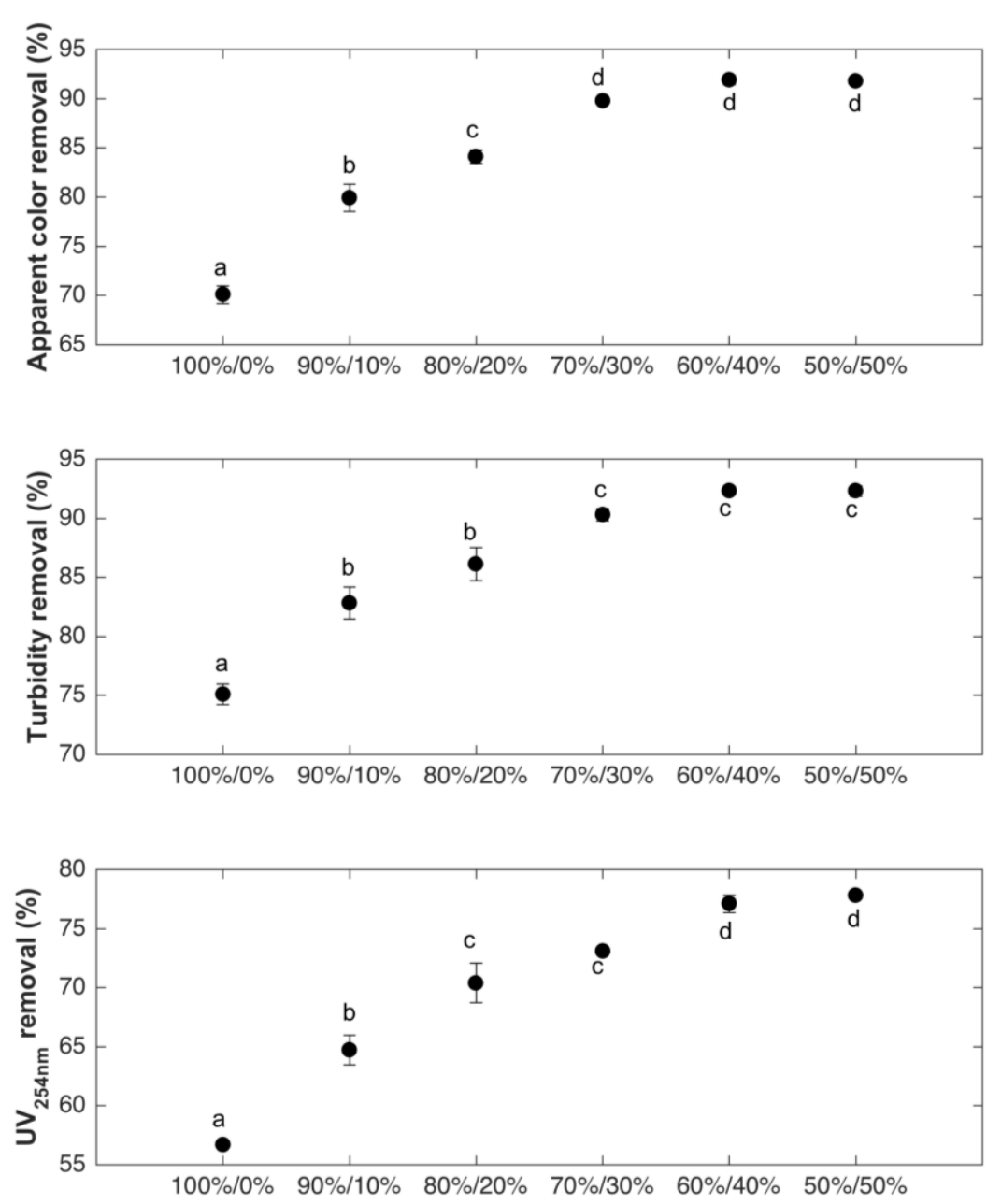

Figure 2. Removal efficiency using different proportions of synthetic and natural coagulants (MO/PAC).

"The results with the same letter do not differ statistically by Tukey Test at a $5 \%$ significance level.

Figure 2 show removal efficiencies above $90 \%$ for apparent color and turbidity quality parameters, using MO/PAC dosages from $70 \% / 30 \%$ to $50 \% / 50 \%$, with no significant statistical differences between them. The best $\mathrm{UV}_{254 \mathrm{~nm}}$ removal efficiencies lie close to $80 \%$ at dosages $60 \% / 40 \%$ and $50 \% / 50 \%$ of MO/PAC.

According to Ghebremichael et al. (2009), MO is a viable coagulant in the partial replacement of synthetic coagulants. However, the association of coagulants used in the coagulation/flocculation and sedimentation processes is not sufficient to produce drinking water. $\mathrm{Tt}$ is therefore necessary to add a filtration stage to improve the quality of treated water.

Considering that MO/PAC $80 \% / 20 \%$ and $60 \% / 40 \%$ dosages showed the best removal efficiencies, it was decided to study their effectiveness in the other stages of this work. The removal efficiency was around $85 \%$ for apparent color and turbidity and $71 \%$ for $\mathrm{UV}_{254 \mathrm{~nm}}$ absorption with MO/PAC dosages of $80 \% / 20 \%$ and around $92 \%$ for apparent color and turbidity and $77 \%$ for $\mathrm{UV}_{254 \mathrm{~nm}}$ absorption with MO/PAC dosages of $60 \% / 40 \%$.

A control experiment was carried out using PAC as the coagulant. The removal efficiency was around $95 \%$ for apparent color and turbidity and $90 \%$ for $\mathrm{UV}_{254 \mathrm{~nm}}$ absorption. Although the results were positive, aluminium salts used as a primary coagulant in water treatment may lead to increased concentrations of aluminium ions in drinking water (Muyibi and Alfugara, 2003) that may be related to neurological diseases besides accelerating the degenerative process

\section{IPABH}


of Alzheimer's disease (Joshua and Vasu, 2013). Thus, it is important to decrease the dosage of the PAC coagulant used in coagulation/flocculation process.

The observed results for floc sizes and average values of zeta potential are shown in Table 2 , considering only the supernatant after coagulation/flocculation and sedimentation processes for dosages MO/PAC $80 \% / 20 \%$ and $60 \% / 40 \%$.

Table 2. Floc size and zeta potential after coagulation/flocculation and sedimentation processes.

\begin{tabular}{lccc}
\hline Samples & \% Coagulants & ${\text { Zeta potential }(\mathbf{m V})^{(\mathbf{1})}}$ & Floc size $(\mathbf{n m})$ \\
\hline Raw water & - & $-21.00 \pm 0.38^{\mathrm{a}}$ & 3589.5 \\
MO/PAC & $80 \% / 20 \%$ & $-11.56 \pm 0.57^{\mathrm{b}}$ & 31924.6 \\
& $60 \% / 40 \%$ & $-12.80 \pm 0.44^{\mathrm{b}}$ & 47803.1 \\
\hline
\end{tabular}

(1) Results are expressed as mean values \pm standard deviation.

"Means followed by the same letter in the same column do not differ statistically by Tukey Test at a 5\% significance level.

Zeta potential of raw water was $-21.00 \mathrm{mV}$. After the coagulation/flocculation and sedimentation processes, the observed results lie around $-12.00 \mathrm{mV}$. A reduction of zeta potential after treatment with $\mathrm{MO}$ as the association of natural coagulant with aluminum salts has also been observed by other authors (Muyibi and Alfugara, 2003). The addition of synthetic products to a colloidal dispersion causes a destabilisation of flocs by means of zeta potential reduction. According to Muyibi and Alfugara (2003) the change in zeta potential indicated that some charge neutralization had taken place to some degree. Therefore, the proposed coagulation mechanism for MO used as a primary coagulant in the treatment of raw water is a combination of a partial absorption and neutralization of charges, or adsorption and bridge-making in which negative particles of colloids were adsorbed on MO's surface.

Joshua and Vasu (2013) reported that when powder from seeds is added to muddy water, proteins release positive charges, which attract negative-charged entities, such as mud, clay, bacteria and toxic particles in the water. Flocculation occurs when proteins bind themselves to the negative charges and produce flocs by aggregating particles in water (Valverde et al., 2018).

Several studies aimed to isolate and characterize the active coagulant compound present in MO seeds. The coagulation mechanism in aqueous solution seemed to be adsorption and neutralization of charges (Poumaye et al., 2012), based on results obtained by zeta potential (Muyibi and Alfugara, 2003). Ndabigengesere et al. (1995) suggest that the adsorption mechanism and bridge-making processes are also possible. Consequently, the activation mechanism of MO as a coagulant is still undefined (Valverde et al., 2018).

Floc size is a crucial parameter in water treatment processes (Bongiovani et al., 2014). It is also known that large flocs tend to present better removal efficiencies (Wang et al., 2009). Floc size increases significantly with the addition of coagulants in water treatment. It was observed that at lower MO dosages, and, consequently, higher synthetic coagulant dosages, larger flocs are obtained, which corroborates the study of Dalen et al. (2009). The flocs formed with MO aqueous extract are small and fragile, and the sedimentation process is slow (Bongiovani et al., 2014).

Table 3 presents the characterization of water treated by means of the association of coagulants $\mathrm{MO}$ and PAC after the coagulation/flocculation, sedimentation and filtration processes. 
Table 3. Characterization of treated water after the coagulation/flocculation, sedimentation and filtration processes.

\begin{tabular}{|c|c|c|c|c|c|c|}
\hline \multirow{3}{*}{$\begin{array}{l}\text { Quality parameters } \\
\text { (unidade) }\end{array}$} & & & \multicolumn{2}{|c|}{ \% Coagulants (MO/PAC) } & \multicolumn{2}{|c|}{ Values allowed (Legislation) } \\
\hline & Raw water & Control $^{(1)}$ & $80 \% / 20 \%$ & $60 \% / 40 \%$ & \multirow{2}{*}{$\begin{array}{l}\text { BRASIL } \\
(2011)\end{array}$} & \multirow{2}{*}{$\begin{array}{l}\text { USEPA } \\
(2009)\end{array}$} \\
\hline & \multicolumn{4}{|c|}{ Residual values } & & \\
\hline Apparent color $(\mathrm{uH})$ & 376 & 19 & 1 & 1 & 15 & 15 \\
\hline Turbidity (NTU) & 79.0 & 6.0 & 2.6 & 2.0 & 5 & 1 \\
\hline $\mathrm{UV}_{254 \mathrm{~nm}}\left(\mathrm{~cm}^{-1}\right)$ & 0.263 & 0.049 & 0.020 & 0.025 & - & - \\
\hline Temperature $\left({ }^{\circ} \mathrm{C}\right)$ & 20 & 25 & 28 & 27 & - & - \\
\hline $\mathrm{pH}$ & 7.537 & 7.562 & 7.322 & 7.466 & $6.0-9.5$ & $6.5-8.5$ \\
\hline $\mathrm{DOC}\left(\mathrm{mg} \mathrm{L}^{-1}\right)$ & 4.160 & 2.742 & 5.975 & 4.565 & - & - \\
\hline TTHM $\left(\mu \mathrm{g} \mathrm{L}^{-1}\right)^{(2)}$ & 20.8 & 13.5 & 33.8 & 32.2 & 100 & 80 \\
\hline Alkalinity $\left(\mathrm{mg} \mathrm{L}^{-1}\right)$ & 26.0 & 27.0 & 26.0 & 30.0 & - & - \\
\hline Volatile acids $\left(\mathrm{mg} \mathrm{L}^{-1}\right)$ & 42 & 24 & 30 & 18 & - & - \\
\hline Total hardness $\left(\mathrm{mg} \mathrm{L}^{-1}\right)$ & 27.50 & 25.75 & 25.00 & 23.50 & 500 & - \\
\hline $\operatorname{TDS}\left(\mathrm{mg} \mathrm{L}^{-1}\right)$ & 171.0 & 115.00 & 50.00 & 43.00 & 1000 & 500 \\
\hline Total coliforms (CFU) & 1200 & 500 & Absence & 100 & Absence & 0 \\
\hline E. $\operatorname{coli}(\mathrm{CFU})$ & 200 & 200 & Absence & Absence & Absence & 0 \\
\hline
\end{tabular}

(1) Coagulation/flocculation, sedimentation and filtration process carried out just with raw water, without the addition of the coagulants.

(2) According to the TTHM analysis method, $1.5 \mathrm{mg} \cdot \mathrm{L}^{-1}$ of sodium hypochlorite was added to the filtered water and the time of contact was $8 \mathrm{~h}$.

Through the obtained results using the dosages MO/PAC $80 \% / 20 \%$ and $60 \% / 40 \%$, it was possible to observe that, despite occurring a reduction in control residual values for most quality parameters, it could be noted that apparent color, turbidity, total coliforms and E. coli results are close to the maximum values allowed by legislation (Brasil, 2011; USEPA, 2009).

The turbidity parameter did not meet the quality required of water destined for human consumption, according to American legislation (USEPA, 2009). However, as long as the removal efficiency was higher than $95 \%$, the use of $\mathrm{MO}$ in water treatment cannot be discarded.

It was verified that the DOC parameter increased in relation to raw water in a proportional way to the dosage of natural coagulant MO coagulant added to the coagulation/flocculation, sedimentation and filtration processes. Because it is a biodegradable product, the presence of MO tends to increase the organic matter content in treated water (Vieira et al., 2010). Similar results were observed in other studies (Ghebremichael et al., 2009; Awad et al., 2013). Despite the increase in DOC, the use of doses under the concentration of $200 \mathrm{mg} . \mathrm{L}^{-1}$ of MO seed extract recommended to treat water for humans does not pose a risk to human health (Rolim et al., 2011).

In terms of TTHM analysis, the value $20.8 \mu \mathrm{g} . \mathrm{L}^{-1}$ was observed for raw water. After the coagulation/flocculation, sedimentation and filtration processes carried out with the association of coagulants, an increase in residual values higher than 55\% was verified. According to some researchers (Ghebremichael et al., 2005), there is a concern in relation to MO extract because, being rich in organic matter, nutrients and vitamins, it can interfere with disinfectants used in water treatment plants and lead to the formation of TTHM (Ndabigengesere and Narasiah, 1998). It is therefore suggested that the association of MO with the synthetic coagulant PAC is a precursor of TTHM formation. However, the observed values still remain within the range permitted by current legislation.

As for the bacteriological parameters, the absence of total coliforms was verified for an $80 \%$ dosage of MO coagulant combined with $20 \%$ synthetic coagulant. Despite a significant decrease in microbial load, the presence of total coliforms for a $60 \%$ dosage of natural coagulant combined with $40 \%$ PAC could still be observed. According to a recent study (Dasgupta et al., 2016), the antimicrobial effects of MO seeds are attributed to the modification of the 
peptidoglycan backbone of the cell wall. In this way, it can be ascertained that the dosage of natural coagulant interferes with the removal of total coliforms, constituting an indispensable additional step of the disinfection process, so as to render microorganisms inactive and guarantee the production of potable water.

The absence of $E$. coli was ascertained in all samples of treated water analyzed, which was expected, as previous studies (Dasgupta et al., 2016; Suarez et al., 2003) with MO have indicated the bactericidal activity of MO.

Thus, under the studied operational conditions concerning coagulant association, the results found in physical, chemical and microbiological characterization of water were quite impressive and, as a consequence in agreement with the limits required by Brazilian legislation (Brasil, 2011).

\section{CONCLUSIONS}

The utilization of MO can play a key role in reducing the amount of the synthetic coagulant PAC required to obtain treated water. The proposed association of coagulants using $80 \% / 20 \%$ or $60 \% / 40 \%$ of $\mathrm{MO} / \mathrm{PAC}$ resulted in drinking water in accordance with the limits required by Brazilian legislation using a coagulation/flocculation, sedimentation and filtration process under the studied operational conditions. Nevertheless, it is important to perform the disinfection stage in order to assure water potability. In addition, the use of biocoagulants such as MO presents a number of advantages over synthetic coagulants in terms of cost, availability, low sludge volume and effective sludge disposal. The present study demonstrated that natural coagulants could be effectively used to complement synthetic coagulants in water treatment. All benefits and advantages in environmental and public health make this technology competitive both in developing and developed countries.

\section{ACKNOWLEDGEMENTS}

The authors would like to thank Coordenação de Aperfeiçoamento de Pessoal de Nível Superior (CAPES), Conselho Nacional de Desenvolvimento Científico e Tecnológico (CNPq), Financiadora de Estudos e Projetos (FINEP) and Instituto Cesumar de Ciência, Tecnologia e Inovação (ICETI) for funding, Universidade Federal de Sergipe (UFS) and SANEPAR for providing samples of MO seeds and raw water, respectively.

\section{REFERENCES}

AMERICAN PUBLIC HEALTH ASSOCIATION - APHA; AMERICAN WATER WORKS ASSOCIATION - AWWA; WATER ENVIRONMENT FEDERATION - WEF. Standard Methods for the Examination of Water and Wastewater. Washington, 1995.

ANWAR, F.; LATIF, S.; ASHRAF, M.; GILANI, A. H. Moringa oleifera: a food plant with multiple medicinal uses. Phytother Research, v. 21, n. 1, p. 17-25, 2007. https://doi.org/10.1002/ptr.2023

AWAD, M.; WANG, H.; LI, F. Preliminary study on combined use of Moringa seeds extract and PAC for. water treatment. Research Journal of Recent Sciences, v. 2, n. 8, p. 5255, 2013. 
BAPTISTA, A. T. A.; COLDEBELLA, P. F.; CARDINES, P. H. F.; GOMES, R. G.; VIEIRA, M. F.; BERGAMASCO, R.; VIEIRA, A. M. S. Coagulation-flocculation process with ultrafiltered saline extract of Moringa oleifera for the treatment of surface water. Chemical Engineering Journal, v. 276, p. 166-173, 2015. https://doi.org/10.1016/j.cej.2015.04.045

BHUPTAWAT, H.; FOLKARD, G. K.; CHAUDHARI, S. Innovative physico-chemical treatment of wastewater incorporating Moringa oleifera seed coagulant. Journal of Hazardous Materials, v. 142, n. 1-2, p. 477-482, 2007. https://doi.org/10.1016/j.jhazmat.2006.08.044

BONGIOVANI, M. C.; CAMACHO, F. P.; NISHI, L.; COLDEBELLA, P. F.; VALVERDE, K. C.; VIEIRA, A. M. et al. Improvement of the coagulation/flocculation process using a combination of Moringa oleifera lam with anionic polymer in water treatment. Environmental Technology, v. 35, n. 17-20, p. 2227-36, 2014. https://doi.org/10.1080/09593330.2014.899398

BONGIOVANI, M. C.; CAMACHO, F. P.; VALVERDE, K. C.; SANTOS, T. R. T.; NISHI, L.; BERGAMASCO, R. Evaluation of trihalomethanes formation using combined process coagulation/floculation/membranes in water treatment. Chemical Engineering Transactions, v. 43, p. 6, 2015.

BRASIL. Ministério da Saúde. Portaria no 2.914, de 12 de dezembro de 2011. Dispõe sobre os procedimentos de controle e de vigilância da qualidade da água para consumo humano e seu padrão de potabilidade. Diário Oficial [da] União, Brasília, 14 dez. 2011. Seção 1, p. 39.

DALEN, M. B.; PAM, J. S.; IZANG, A.; EKELE, R. Synergy Between Moringa oleifera seed powder and alum in the purification of domestic water. Science World Journal, v. 4, n. 4, 2009. http://dx.doi.org/10.4314/swj.v4i4.51400

DASGUPTA, S.; KUMAR GUNDA, N. S.; MITRA, S. K. Evaluation of the antimicrobial activity of Moringa oleifera seed extract as a sustainable solution for potable water. RSC Advances, v. 6, n. 31, p. 25918-25926, 2016. http://dx.doi.org/10.1039/C6RA04011J

DAVID, C.; NARLAWAR, R.; ARIVAZHAGAN, M. Performance Evaluation of Moringa oleifera Seed Extract (MOSE) in Conjunction with Chemical Coagulants for Treating Distillery Spent Wash. Indian Chemical Engineer, v. 58, n. 3, p. 189-200, 2016. https://doi.org/10.1080/00194506.2015.1006147

FERREIRA, D. F. Sisvar: a computer statistical analysis system. Ciência e Agrotecnologia, v. 35, p. 1039-1042, 2011. ttp://dx.doi.org/10.1590/S1413-70542011000600001

FREITAS, J. H. E. S.; DE SANTANA, K. V.; DO NASCIMENTO, A. C. C.; DE PAIVA, S. C.; DE MOURA, M. C.; COELHO, L. C. B. B. et al. Evaluation of using aluminum sulfate and water-soluble Moringa oleifera seed lectin to reduce turbidity and toxicity of polluted stream water. Chemosphere, v. 163, p. 133-141, 2016. https://doi.org/10.1016/j.chemosphere.2016.08.019

GHEBREMICHAEL, K.; ABALIWANO, J.; AMY, G. Combined natural organic and synthetic inorganic coagulants for surface water treatment. Journal of Water Supply: Research and Technology - Aqua, v. 58, n. 4, p. 267-276, 2009. http://dx.doi.org/10.2166/aqua.2009.060 
GHEBREMICHAEL, K. A.; GUNARATNA, K. R.; HENRIKSSON, H.; BRUMER, H.; DALHAMMAR, G. A simple purification and activity assay of the coagulant protein from Moringa oleifera seed. Water Research, v. 39, n. 11, p. 2338-2344, 2005. https://doi.org/10.1016/j.watres.2005.04.012

JOSHUA, R.; VASU, V. Characteristics of stored rain water and its treatment technology using Moringa seeds. International Journal of Life Sciences Biotechnology and Pharma Research, v. 2, n. 1, p. 19, 2013.

MENEGHEL, A. P.; GONÇALVES JR., A. C.; STREY, L.; RUBIO, F.; SCHWANTES, D.; CASARIN, J. Biosorption and removal of chromium from water by using moringa seed cake (Moringa oleifera Lam.). Química Nova, v. 36, p. 1104-1110, 2013. http://dx.doi.org/10.1590/S0100-40422013000800005

MUYIBI, S.; ALFUGARA, A. Treatment of surface water with Moringa oleifera seed extract and alum - a comparative study using a pilot scale water treatment plant. International Journal of Environmental Studies, v. 60, n. 6, p. 9, 2003. https://doi.org/10.1080/723032000087925

NDABIGENGESERE, A.; NARASIAH, K. S.; TALBOT, B. G. Active agents and mechanism of coagulation of turbid waters using Moringa oleifera. Water Research, v. 29, n. 2, p. 703-710, 1995. https://doi.org/10.1016/0043-1354(94)00161-Y

NDABIGENGESERE, A.; NARASIAH, K. S. Quality of water treated by coagulation using Moringa oleifera seeds. Water Research, v. 32, n. 3, p. 781-791, 1998. https://doi.org/10.1016/S0043-1354(97)00295-9

PISOI, I. Coagulation of Surface Water using Simple and Prehydrolyzed Aluminium Salts. Revista de Chimie, v. 62, n. 5, p. 575-578, 2011.

POUMAYE, N.; MABINGUI, J.; LUTGEN, P.; BIGAN, M. Contribution to the clarification of surface water from the Moringa oleifera: Case M'Poko River to Bangui, Central African Republic. Chemical Engineering Research and Design, v. 90, n. 12, p. 23462352, 2012. https://doi.org/10.1016/j.cherd.2012.05.017

ROLIM, L. A.; MACEDO, M. F.; SISENANDO, H. A.; NAPOLEAO, T. H.; FELZENSZWALB, I.; AIUB, C. A. et al. Genotoxicity evaluation of Moringa oleifera seed extract and lectin. Journal of Food Science, v. 76, n. 2, p. T53-8, 2011. https://doi.org/10.1111/j.1750-3841.2010.01990.x

SRIVASTAVA, V. C.; MALL, I. D.; MISHRA, I. M. Treatment of pulp and paper mill wastewaters with poly aluminium chloride and bagasse fly ash. Colloids and Surfaces A: Physicochemical and Engineering Aspects, v. 260, n. 1-3, p. 17-28, 2005. https://doi.org/10.1016/j.colsurfa.2005.02.027

SUAREZ, M.; ENTENZA, J. M.; DOERRIES, C.; MEYER, E.; BOURQUIN, L.; SUTHERLAND, J. et al. Expression of a plant-derived peptide harboring water-cleaning and antimicrobial activities. Biotechnology and Bioengineering, v. 81, n. 1, p. 13-20, 2003. https://doi.org/10.1002/bit.10550

TUKKI, O. H.; BARMINAS, J. T.; OSEMEAHON, S. A.; ONWUKA, J. C.; DONATUS, R. A. Adsorption of colloidal particles of Moringa oleifera seeds on clay for water treatment applications. Journal of Water Supply: Research and Technology - Aqua, v. 65, n. 1, p. 75-86, 2016. http://dx.doi.org/10.2166/aqua.2015.029 
UNITED STATES. Environmental Protection Agency - USEPA. National Primary Drinking Water Regulations. Washington, 2009.

VALVERDE, K. C.; COLDEBELlA, P. F.; NISHI, L.; SANTOS, T. R. T.; SANTOS, O. A. A.; BERGAMASCO, R. Otimização dos parâmetros de operação no processo de coagulação/floculação e sedimentação no tratamento de água com a associação PAC e Moringa oleifera Lam. Engevista, v. 17, n. 14, p. 8, 2015. https://doi.org/10.22409/engevista.v17i4.619

VALVERDE, K. C.; MORAES, L. C. K.; BONGIOVANI, M. C.; CAMACHO, F. P.; BERGAMASCO, R. N. Coagulation diagram using the Moringa oleifera Lam and the aluminium sulphate, aiming the removal of color and turbidity of water. Acta $\begin{array}{llllllll}\text { Scientiarum } & \text { Technology, } & \text { v. } 35, & \text { n. } & 3, & \text { p. } & 5,\end{array}$ http://dx.doi.org/10.4025/actascitechnol.v35i3.12268

VALVERDE, K. C.; NISHI, L.; SALCEDO VIEIRA, A. M.; BONGIOVANI, M. C.; COLDEBELLA, P. F.; MADRONA, G. S. et al. Optimization of process conditions in water treatment through coagulation diagrams, using Moringa oleifera Lam and aluminium sulphate. Desalination and Water Treatment, v. 56, n. 7, p. 1787-1792, 2015. https://doi.org/10.1080/19443994.2014.960470

VALVERDE, K. C.; COLDEBEllA, P. F.; SALCEDO VIEIRA, A. M.; NISHI, L.; BONGIOVANI, M. C.; BAPTISTA, A. T. A. et al. Preparations of Moringa oleifera seeds as coagulant in water treatment. Environmental Engineering and Management Journal, in press, 2018.

VIEIRA, A. M. S.; VIEIRA, M. F.; SILVA, G. F.; ARAÚJO, Á. A.; FAGUNDES-KLEN, M. R.; VEIT, M. T. et al. Use of Moringa oleifera Seed as a Natural Adsorbent for Wastewater Treatment. Water, Air, and Soil Pollution, v. 206, n. 1, p. 273-281, 2010. https://doi.org/10.1007/s11270-009-0104-y

WANG, Y.; GAO, B. Y.; XU, X. M.; XU, W. Y.; XU, G. Y. Characterization of floc size, strength and structure in various aluminum coagulants treatment. Journal of Colloid and $\begin{array}{llllllll}\text { Interface } & \text { Science, } & \text { v. } & 332, & \text { n. } & 2, & \text { p. } & 354-359,\end{array}$ https://doi.org/10.1016/j.jcis.2009.01.002

WORLD HEALTH ORGANIZATION WHO UNICEF. Progress on Sanitation and Drinking Water - 2015 update and MDG assessment. Geneva, 2015. 90p.

YIN, C. Y. Emerging usage of plant-based coagulants for water and wastewater treatment. $\begin{array}{llllllll}\text { Process Biochemistry, } & \text { v. 45, n. 9, p. 1437-1444, }\end{array}$ https://doi.org/10.1016/j.procbio.2010.05.030

ZOUBOULIS, A. I.; TZOUPANOS, N. Alternative cost-effective preparation method of polyaluminium chloride (PAC) coagulant agent: Characterization and comparative application for water/wastewater treatment. Desalination, v. 250, n. 1, p. 339-344, 2010. https://doi.org/10.1016/j.desal.2009.09.053 